\title{
KIAI NU DALAM PERADIGMA POLITIK KEBANGSAAN
}

\author{
Ali Maschan Moesa \\ Anggota Komisi VIII Fraksi Partai Kebangkitan Bangsa DPR RI Periode 2009-20I4
}

\begin{abstract}
Abstrak: Dalam kaitannya dengan wawasan kebangsaan, pemikiran politik NU selalu memadukan antara nilai kebangsaan dengan nilai keagamaan (Islam). Perpaduan antara keduanya didasarkan pada landasan hukum Islam yang memberikan pedoman bahwa Islam tidak mengenal pemisahan agama dari politik. Menurut Gus Dur, hubungan antara agama dan negara harus terjalin secara proporsional. Hal ini dimaksudkan agar proses berfikir kaum muslimin tidak mengganggu perkembangan negara yang sedang merintis dan membangun tatanan negara yang mantap dan berfungsi untuk jangka panjang. Sikap politik tersebut merupakan perwujudan dan perpaduan antara wawasan keagamaan dengan wawasan kebangsaan.

Berdasarkan sikap politik kemasyarakatan tersebut dan sesuai dengan budaya politik Indonesia, pemikiran politik NU selalu terbingkai pada sikap selektif, akomodatif, dan integratif dengan tetap memegang teguh nilai dan prinsip dasar yang telah ditetapkan. Sikap demikian diterapkan oleh NU dalam menjawab setiap permasalahan baru yang muncul dan mencarikan pemecahannya tanpa menimbulkan gejolak.

Kata Kunci: Kiai, Kebangsaan, NU, Politik
\end{abstract}

\section{Pendahuluan}

Kiprak para kiai dalam perjalanan bangsa ini tidaklah kecil. Lewat Islamisasi yang dilakukan oleh para wali, umat Islam akhirnya menjadi mayoritas. Perlawanan fisik dengan menjajah serta pertarungan wacana saat menentukan arah dan bentuk negara, mereka tampil dengan semangat cinta tanah air yang tinggi. Membincang 'negara' selalu menarik terutama jika dikaitkan dengan agama. Kalangan kiai pesantren memahami ada realisasi antara agama dan negara, terutama dalam konteks Indonesia yang pluralistik. Karena itu sebagaian tokoh kalangan kiai pesantren sering memandang Indonesia sat ini tidak ubahnya 
Madinah di awal kepemimpinan Rasulullah SAW yang memiliki ragam etnik dan pemeluk agama yang berbeda-beda.

Dinamika umat Islam yang sekilas tergambarkan dalam pembahasan di atas menunjukkan bahwa ada korelasi antara isuisu sosial politik dengan teks keagamaan. Persoalan menjadi bisa ketika teks keagamaan dijadikan alat legitimasi politik. Sejarah panjang kalangan kiai pesantren juga tidak dapat menghindarkan diri dari perdebatan persoalan tersebut. Jika kita telisik lebih jauh, pada awal berdirinya NU tidak pernah menyinggung tentang syariat Islam. Muktamar III NU pada tahun 1928 yang diadakan di surabaya sebenarnya merupakan momentum tepat untuk merumuskan cita-cita NU karena waktu itu untuk pertama kalinya organisasi ini menetapkan anggaran dasarnya. Ternyata NU masih tidak tertarik membincangkan isu syariah Islam dalam hubungannya dengan negara. Pada waktu itu NU hanya sebatas menetapkan dirinya menjadi supervisor atas tradisi dengan mempertahankan ajaran ke empat mazhab, meskipun pada kenyataannya Mazhab Syafi'i yang dianut oleh kebanyakan umat Islam di Nusantara. NU mulai membincang syariah Islam ketika muktamar XI di Banjarmasin 19 Robiul awal $1355 \mathrm{H}$ yang bertepatan dengan 9 Juni 1936. Ketika mengemuka pertanyaan yang cukup mendasar: Apakah Nahdlatul Ulama menganggap bahwa daerah Betawi, termasuk juga pulau Jawa (Indonesia-pen) sebagai negara harbi (non Muslim)? Saat itu peserta Muktamar yang didominasi oleh para kiai pesantren berkesimpulan bahwa negara Hindia-Belanada saat itu adalah dar Islam (negara yang didalami umat Islam). Para ulama menegaskan:

“...Berangkat dari argumentasi di atas maka dapat dipahami bahwa tanah Betawi (Jakarta) bahkan seluruh pulau Jawa merupakan dar Islam (daerah Islam) karena daerah tersebut pernah dikuasai oleh umat Islam sebelum berada dalam genggaman orang kafir." 


\section{Agama dan Politik}

Agama yang dimaksud disini adalah agama yang bersentuhan dengan tindakan manusia yang diyakini kebenarannya, yang keyakinan tersebut mempengaruhi tindakantindakannya. Atau dalam ungkapan lain, agama menjadi pedoman dalam menginterpretasikan tindakan-tindakannya. ${ }^{1}$ Menurut Smith, agama dapat dianalisis ke dalam empat aspek, yaitu identitas kelompoknya, pengaturan kemasyarakatannya, organisasinya, dan sistem keyakinannya. ${ }^{2}$

Dilihat dari pentingnya agama bagi manusia, Surbakti menyatakan ada dua konsep mendasar agama bagi kehidupan manusia, yaitu agama dalam arti what does religion do for other dan what is religion for other. Pengertian pertama mengacu kepada apa fungsi agama bagi kehidupan manusia dan pengertian yang kedua mengacu kepada apa makna agama bagi manusia. ${ }^{3}$ Mengenai hubungan antara agama dan negara dalam konteks religio-politik, Smith mengajukan dua model sistem, yaitu model organik dan model gereja. ${ }^{4}$ Model organik adalah konsep tentang penggabungan fungsi-fungsi keagamaan dan politik yang dilakukan oleh struktur yang tunggal. Penguasa menjalankan kekuasaan duniawi dan spiritual keagamaan sekaligus, dan fungsi utamanya adalah menegakkan tata sosial yang bersifat ketuhanan sesuai dengan hukum dan tradisi agama yang sakral. Yang termasuk dalam model ini adalah agama Islam dan Hindu. Sedangkan model gereja, ditandai dengan ikatan yang erat antara dua lembaga yang berbeda satu sama lain, yaitu pemerintah dan institusi keagamaan. Namun antara satu dan lainnya dapat bertukar fungsi secara ekstensif di bidang politik dan keagamaan.

Parsudi Suparlan, Kata Pengantar dalam Roland Robertson, Agama dalam Analisa dan Interpretasi Sosiologis, Jakarta: Rajawali Press, I998, h. v-vi.

2 Donald Eugene Smith, Agama dan Modernisasi Politik, suatu Kajian Analitis, Jakarta: Rajawali Press, 1985, h. 187.

${ }^{33}$ Ramlan Surbakti, Antara Fenomena Keagamaan dan Ekonomi-Politik, dalam Surabaya Post, 20 Oktober 1996.

${ }^{4}$ Donald E. Smith, Op. Cit., h. 13. 
Secara empirik, kedua lembaga itu memang terpisah; karenanya hubungan keduanya dapat menggunakan tiga bentuk, yaitu 1) gereja di atas pemerintah, 2) pemerintah di atas gereja, 3) dengan keseimbangan kekuasaan antara keduanya. Yang termasuk dalam ini menurut Smith adalah agama Katolik dan agama Budha.

Studi-studi teoritis yang dilakukan para ahli keislaman, kebanyakan berada dalam perspektif hubungan negara dan masyarakat. Sehingga khazanah studi yang lebih makro, yaitu membahas hubungan interaksional antara ajaran Islam dengan tindakan politik kurang disentuh. Kalaupun ada, masih sangat sedikit. Para ahli, termasuk kalangan orientalis yang di dalamnya juga Watt menyatakan, dalam Islam terdapat sistem pemerintahan, dimana terdapat konstitusi yang disebutnya sebagai Konstitusi Madinah. Demikian pula sistem kekhalifahan Islam berikutnya merupakan bentuk pemerintahan Islam. Memang pada awalnya, gerakan Muhammad bukanlah gerakan politik, hanya gerakan keagamaan. Akan tetapi lambat laun setelah Nabi pindah ke Madinah dan memiliki kekuatan untuk mengkooptasi wilayahwilayah lain, maka secara politik telah diakui. ${ }^{5}$

Dalam pandangan teoritis ini wilayah agama dan negara tidak dapat dipisahkan, wilayah agama juga meliputi wilayah politik dan negara. Karenanya, menurut paradigma ini negara merupakan lembaga politik dan keagamaan sekaligus. Pemerintahan negara diselenggarakan atas dasar kedaulatan ilahi (divine sovereignty), karena kadaulata itu memang berasal dari dan berada di tangan Tuhan. Pandangan inilah yang disebut juga sebagai fundamentalisme Islam. Secara faktual yang terutama dalam paradigma ini ialah hubungan antara agama dan negara di Iran. Oleh karena itu, Iran dinamakan sebagai negara teokratis. Negara model ini mengandung unsur pengertian, kekuasaan mutlak berada di tangan Tuhan, san konstitusi negara berdasarkan pada wahyu Tuhan (syariat). Sifat teokratis negara dalam

\footnotetext{
${ }^{5}$ W. Montgomery Watt, Politik Islam dalam Lintasan Sejarah, Jakarta: P3M, 1988, h. 3-5.
} 
pandangan Syiah misalnya dapat ditemui pada pikiran politik Khomaeni. ${ }^{6}$ Konsep-konsep utama dari sistem pemerintahan Iran adalah imamah, vilayat al-faqih, dan ishmah (kesucian dari dosa yang hanya dimiliki oleh keturunan Nabi).

Pandangan al-Maududi (1903-1979). Menurutnya, syariat tidak mengenal pemisahan antara agama dan politik atau antara agama dan negara. Syariat merupakan totalitas pengaturan kehidupan manusia yang tidak mengandung kekurangan sedikitpun. Negara harus didasarkan pada empat prinsip, yaitu mengakui kedaularan Tuhan, menerima otoritas Nabi Muhammad, memiliki status wakil Tuhan dan menerapkan musyawarah. ${ }^{7}$ Menurut Maududi, institusi negara Islam terdiri dari kepala negara dan lembaga legislatif. Posisi pentingnya terletak di kepala negara yang disebut sebagai imam, khalifah, atau amir. Kepala negara memiliki wewenang sangat besar, bahkan dapat menveto keputusan bulat yang disepakati Badan Penasehat, dengan catatan bahwa kepala negara tersebut wajib ditaati selama mematuhi perintah Tuhan. ${ }^{8}$

Pemikiran al-Mawardi yang nama lengkapnya Abu Hasan ibn Muhammad ibn Habib al-Mawardi (974-1058). Tulisanya yang sangat terkenal di bidang teori ketatanegaraan ialah al-Ahkam alSulthaniyah. Dalam pandangannya, pemimpin negara (imamah) merupakan instrumen untuk meneruskan misi kenabian guna memelihara agama dan mengatur dunia. Pemeliharaan dan pengaturan dunia adalah dua dimensi yang berhubungan secara secara simboitik. Negara, dengan demikian dibawah kontrol

${ }^{6}$ Din Syamsudin, Usaha Pencarian Konsep Negara dalam Sejarah Pemikiran Politik Islam, dalam Ulumul Qur'an, no. 2, vol. IV, 1993, h. 6. Iran juga disebut sebagai negara teodemokratis dan bukan teokratis, sebab dalam pemilihan kepada negara tetap menyertakan partisipasi masyarakat. Untuk itu, periksa Haidar Baqir, "Republik Islam Iran; Revolusi menuju Teodemokratis", dalam Imam Azis, Agama, Demokrasi dan Keadilan, Jakarta: Gramedia, 1993, h. 30-4l.

7 Periksa Munawir Sadzali, Islam dan Tata Negara; Ajaran Sejarah dan Pemikiran, Jakarta: UI Press, 1995, h. 166.

${ }^{8}$ Ahmad Jauhari, Pemikiran Mawdudi tentang Negara Islam, dalam Sudarnoto Abdul Hakim, Islam berbagai Perspektif, Jakarta: LPMI, 1995, h. 181-200. 
agama. Dalam pengankatan kepala negara melalui sebuah pemilihan, ia membagi umat Islam menjadi dua kelompok, ahl alikhtiyar dan ahl al-imamah. Yang pertama diartikan sebagai kelompok masyarakat yang dapat memberikan wewenang kepada kepala negara untuk mengatur masyarakat melalui proses pemilihan terlebih dahulu. Ada beberapa syarat yang harus dipenuhi yaitu adil, berilmu pengetahuan, khususnya ilmu agama, tidak cacat fisik, mempunyai wawasan politik, ahli strategi perang dan mempunyai garis keturunan Quraisy. ${ }^{9}$

Pemikir lain adalah al-Ghazali atau Abu Hamid al-Ghazali (1058-1111 M). Bukunya yang sangat terkenal ialah Ihya "Ulum aldin, atau agama. Menurutnya, negara dibutuhkan oleh masyarakat berkaitan dengan pemenuhan kebutuhan akan industri, profesi dan kepala negara yang memiliki legitimasi keafamaa. Industri yang dibutuhkan untuk kepentingan masyarakat ialah pertanian, pemintalan yang didukung pembangunan dan politik. Profesi politik yang dibutuhkan untuk kepentingan masyarakat ialah subprofesi pengukuran tanah, sub-profesi ketentaraan, sub-profesi kehakiman, dan sub-profesi ketentaraan, dan sub-profesi ilmu hukum. Begitu pentingnya sub-profesi politik tersebut, al-Ghazali menyatakan bahwa kedudukanya satu tingkat di bawah kenabian. ${ }^{10}$ Pemilihan kepala negara bukan keharusan urusan rasio, tetapi keharusan urusan agama. Hal ini didasari oleh persiapan untuk kesejahteraan ukhrawi harus dilakukan melalui pengamalan dan penghayatan agama di dunia secara benar. Inilah yang dijadikan sebagai argumentasi bahwa antara negara dan agama merupakan dua hal yang saling membutuhkan. Untuk kepentingan memimpin masyarakat dalam mewujudkan kemakmuran, maka al-Ghazali mensyaratkan kepala negara harus dewasa, berotak yang sehat, merdeka (bukan budak), laki-laki,

9 Fathurrahman Jamil, Al -Mawardi, Mekanisme Pengangkatan dan Pemberhentian Kepala Negara, dalam Sudarnoto Abdul Hakim, Islam Berbagai Perspektif, Jakarta: LPMI, 1995. H. I58-160.

${ }^{10}$ Munawir Sadzali, Op. Cit., h. 75. 
keturunan Quraisy, memiliki pendengaran dan pengliharan sehat, kekuasaan yang nyata, hidayah, ilmu pengetahuan dan wira'i (menjaga diri dari harta yang tidak halal). ${ }^{11}$

Ada tokoh yang memandang hubungan antara agama dan negara ialah terpisah atau bersifat sekularistik. Pandangan ini menolak baik hubungan simbiotik maupun integrated. Ali Abd alRaziq (1888-1966 M), pada tahun 1925 menulis buku yang kontroversial dan menyebabkan ia terusir dari pemerintahan Mesir, ialah berjudul Islam wa Ushul al-Hukm (Islam dan prinsipprinsip pemerintahan). Raziq berpendapat bahwa tugas Nabi Muhammad tak lebih dari tugas kenabian sebagaimana nabi-nabi sebelumnya. Di samping itu, urusan keduniaan oleh Nabi Muhammad juga diserahkan kepada manusia, yang menurutnya termasuk urusan politik. ${ }^{12}$ Lebih jauh ia menyatakan Islam tidak memiliki kaitan apa pun dengan sistem kekhalifahan, sehingga semua sistem kekhalifahan adalah urusan duniawi. Jadi, terdapat penolakan terhadap determinasi Islam akan bentuk tertentu dari negara. ${ }^{13}$

Selanjutnya, tentang hubungan Islam dan negara di Indonesia, menurut Adnan dapat dibagi menjadi tiga kategori. Pertama, kelompok akomodatif yang difigurkan oleh Nurcholis Madjid, di mana dia berpandangan bahwa kehidupan spiritual diatur oleh agama dan kehidupan duniawi diatur oleh logika duniawi. ${ }^{14}$ Pandangan ini berakibat Islam lebih berwatak liberalis dan humanis yang menawarkan kebebasan dan kemanusiaan bagi penganutnya, dari pada watak politis yang menakutkan, utamanya bagi penyelenggara negara. ${ }^{15}$ Di kalangan Nahdlatul Ulama (NU) pemikiran akomodatif dapat dilihat pada diri

\footnotetext{
"' Munawir Sadzali, Ibid., h. 76-79.

12 Munawir Sadzali, Ibid., h. $143-145$

${ }^{13}$ Din Syamsudin, Op. Cit., h. 7-8.

${ }^{14}$ Zifirdaus Adnan, Islam Religion Yes, Political Ideology No. Islam and the State in Indonesia, dalam artikel Arief Budiman, State and Civil Society (Clyton, Victoria: Centre of South East Asian Studies, 1992), h. 458.

15 Muhammad Kamal Hasan, Modernisasi Indonesia; Respon Cendekiawan Muslim, Surabaya: Bina IImu, 1987, h. 231-240
} 
Abdurrahman Wahid (Gus Dur) dimana sukses menarik gerbong NU ke khittah 1926 yang intinya ialah memisahkan NU dari politik dan bukan sebagai institusi. Artinya bahwa konsekuensi logis dari khittah adalah tidak ada politik Islam dan selanjutnya juga tidak ada lembaga politik Islam atau dengan kata lain menegaskan pentingnya lembaga politik Islam. ${ }^{16}$ Kedua, kelompok moderat, dengan toko Amien Rais, Jalaluddin Rahmat dan Imaduddin yang berpendirian bahwa Islam tidak hanya dipahami sebagai agama, akan tetapi juga sebagai ideologi. Untuk ini berbeda dengan kelompok akomodatif yang menginginkan perubahan dari dalam negara, kelompok moderat justru menginginkan perubahan dari luar negara. Ketiga, kelompok idealis radika, yang beranggapan bawa Islam berada di atas semua ideologi, sehingga untuk memperjuangkannya diperlukan caracara kekerasan dan sekaligus menolak ideologi Pancasila sebagai satu-satunya azas bagi kehidupan organisasi sosial kemasyarakatan dan menggantikan agama dengan ideologi Pancasila.

\section{Umat Islam dalam Format Politik Nasional}

Pembicaraan tentang politik di indonesia, hampir pasti tidak dapat dipisahkan dengan peran umat Islam. Umat Islam sebagai mayoritas penduduk Indonesia memiliki potensi sebagai legitimasi politik untuk turut mensukseskan pembangunan nasional. Dengan kuantitasnya ini umat Islam memiliki bargaining position yang kuat terhadap negara. Dari segi jumlah saja, umat Islam diharapkan (seharusnya) memiliki daya tawar menawar kuat dengan pemegang kekuasaan. Sebagai agama yang dianut oleh mayoritas pendududk, terutama saja Islam memerlukan kekuasaan politik sebagai instrumen untuk menjamin pelaksanaan

\footnotetext{
${ }^{16}$ Abdurrahman Wahid, Poitik Sebagai Moral, Bukan Institusi, dalam Prisma, No. 5, 1995, h.6669. Periksa pula Laode Ida, Kembali ke Khittah 1926, Membangun Gerakan Politik Kultural NU, dalam Prisma, No.5, h.87-100.
} 
ajaran-ajaran dalam kehidupan masyarakat, berbangsa dan bernegara.

Dalam sejarah, terutama kala masa kolonial, Islam menjadi identitas perjuangan bangsa Indonesia dalam menghadapi penjajah. Pertarungan dalam segala bentuk, dari hal yang besifat konsepsional maupun konseptual menjadi fenomena yang tidak terelakkan dalam merespon kehadiran "orang-orang asing" tersebut di negeri ini. Untuk mengkaji peran politik umat Islam secara lengkap dan utuh, rasanya tidak mungkin hanya melalui forum terbatas ini. Secara kualitas maupun kuantitas, umat Islam paling banyak berjasa dalam pembentukan bangsa ini. Andaikan Biro Pusat Statistik (BPS) melakukan sensus ke taman makam pahlawan mulai dari wilayah Sabang sampai Merauke tentang agama mereka yang telah gugur, kita akan tahu bahwa darah dan nyawa umat Islam-lah yang paling banyak memberikan sumbangan pada upaya memperjuangkan dan mempertahankan negara tercinta ini. Belum lagi dapat dihitung, berapa kerugian harta benda dan berbagai aset yang dimiliki oleh umat Islam dalam upaya membela eksistensi negara ini.

Ketika ramai dibicarakan tentang Pancasila sebagai satusatunya asas keorganisasian, pro dan kontra terjadi selama kurang lebih 3 (tiga) tahun hingga diundangankannya UU No. 5/1985. Gagasan asas tunggal disampaikan pertama kali oleh Presiden Soeharto pada pidato kenegaraan di depan Sidang Pleno DPR tanggal 16 Agustus 1982.17 Ketika belum satupun ormas yang menerima, umat Islam yang dipelopori oleh Nahdlatul Ulama (NU) tampil pertama kali untuk menerima dan menjadikan Pancasila sebagai asas organisasinya.

Disamping terdapat pengalaman positif hubungan Islam dan negara, juga kita mengalami trauma psikologis ketika terjadinya pembangkangan (pemberontakan) terhadap negara yang dilakukan oleh umat Islam. Tengoklah bagaimana peristiwa Darul

${ }^{17}$ Departemen Penerangan, Pidato Kenegaraan Republik Indonesia Soeharto di Depan Dewan Perwakilan Rakyat, 16 Agustus 1982.

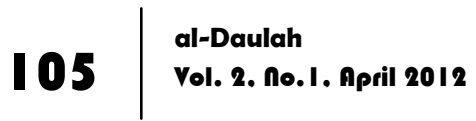


Islam di Jawa Barat dibawah pimpinan Kartosuwiryo. ${ }^{18}$ Di wilayah Sulawesi Utara dengan Kahar Muzakkarnya, serta PRRI/Permesta ${ }^{19}$ di Sumatera dan Sulawesi Utara. Belum lagi kasus Tanjung Priok ${ }^{20}$, peristiwa GPK Warsidi Lampung ${ }^{21}$ dan barisan Jubah Putih di Aceh. ${ }^{22}$ Semua 'pemberontakan' tersebut membekas pada diri pejabat pemerintah dan ABRI (sekarang TNI) sebagai Islam-phobi. Itulah sebabnya pemerintah (kala itu) kadang perlu melakukan political test kepada umat Islam.

Akan tetapi, untunglah trauma masa lalu sudah dihilangkan. Sekarang, negara sudah melihat Islam dengan mata hati yang jernih. Semakin menguatnya hegemoni umat Islam pada giliannya melahirkan berbagai analisis tentang model strategi perjuangan umat yang kondusif dan representatif untuk memperjuangkan kepentingan umum. Hal ini ditandai dengan munculnya polemik pemikiran dua orang tokoh yang dianggap sebagai mainstream dan mewakili model perjuangan umat Islam yang selama ini dilakukan. Dua tokoh tersebut adalah Abdurrahman Wahid (Gus Dur) dan Amien Rais.

Gus Dur dikenal dengan gaya kulturalnya. Sementara itu Amien Rais dikenal dengan tipe struktural birokrasi, lembagalembaga negara dan usaha-usaha yang mengarah pada pengambilan keputusan politik. Oleh karena garis perjuangannya cenderung berkiprah pada elit politik, maka sering pula disebut

\footnotetext{
${ }^{18}$ Studi intensif dan integral seputar gerakan DI/TII periksa umpamanya dalam C. Van Dirjk, Darul Islam; Sebuah Pemberontakan, Jakarta: Grafiti Pres, 1984. Sedangkan untuk peristiwa serupa yang terjadi di Jawa barat periksa antara lain pada Karl D. Jackson, Kewibawaan Tradisional, Islam dan Pemberontakan; Kasus Darul Islam di Jawa Barat, Jakarta: Grafiti, 1990.

${ }^{19}$ Gambaran yang jelas terhadap kronologis peristiwa tersebut antara lain dapat dilihat pada; S. Harvey, Permesta; Pemberontakan Setengah Hati, Jakarta: Grafiti Pres, 1984.

${ }^{20}$ Dalam Kasus ini banyak terjadi kesimpangansiuran sejarah. Karena itu beberapa kalangan ada yang menginginkan agar peristiwa ini dapat diusut ulang. Sekedar perbandingan, lihat antara lain pada Sinar Harapan, I Juni 1985, atau pada Panji Masyarakat, 2 I September 1984. Kemudian bandingkan fakta-fakta tersebut dengan Julius Pour, Benny Moerdani; Profil Prajurit Negarawan, Jakarta: Yayasan Kejuangan Panglima Sudirman, I993, h. 598-5I 0.

${ }^{21}$ Kronologis peristiwa ini dapat dilihat antara pada; Tempo, 30 September 1989, Tempo 18 Februari 1989, h. 14-19.

22 Tempo, 18 Februari 1989, h. 26.
} 
demokrasi atas. Adapun model kultural lebih mengedepankan pembenahan basis sosio-kultural dan politik di tingkat bawah sebagai dasar tegaknya gagasan masyarakat adil dan makmur. ${ }^{23}$ Karena itu, model kedua dikenal domokrasi bawah.

Sudah seharusnya umat Islam menyatukan diri dalam arah dan langkah, agara dapat memposisikan diri sebagai umat yang memiliki keunggulan. Apalagi dalam era globalisasi, dimana keunggulan dan daya saing merupakan prasyarat utama. Semangat ajaran Islam fastabikul khairat, berkompetisi dalam hal posistif harus senantiasa di gelorakan dan dilaksanakan secara integral dan total antara iman dan takwa, ilmu pengetahuan, dan amal shaleh sehingga menjadi jati diri setiap pribadi muslim. Dalam artian, kita akan mengelaborasikannya dengan ilmu-ilmu sosial dan kemanusiaan. Sasaran yang ingin dicapai adalah agar pemikiran itu bisa menemukan relevansinya dengan realitas.

\section{Kiai Pancasila dan Asas Tunggal}

Sebuah negara-bangsa (nation-state) akan berdiri kokoh jika memiliki landasan yang kuat, yaitu ideologi yang merupakan pemersatu, perekat, dan pengikat persatuan dan kesatuan bangsa dan negara. Para pendiri Republik Indonesia telah berhasil meletakkan dasar negara yang kuat dan kokoh, yaitu Pancasila.

Dari enam puluh orang anggota Badan Penyelidik Usaha Persiapan Kemerdekaan Indonesia, hanya sembilan orang dari mereka yang dijadikan Panitia Kecil untuk merumuskan Pancasila sebagai perwujudan dari tujuan dan maksud didirikannya Indonesia merdeka. Kesembilan orang tersebut adalah: Soekarno, Mohammad Hatta, Moammad Yamin, Ahmad Soebardjo, AA. Maramis, Abdul Kahar Muzakir, Abdul Wahid Hasyim, Agus Salim, dan Abikusno Tjokro Sujoso. ${ }^{24}$ Dalam Panitia Sembilan

\footnotetext{
${ }^{23}$ Mengenai dikotomi pola gerakan kedua tokoh panutan ini dikupas pada Arief Affandi, Islam, Demokrasi Atas Bawah, Polemik Strategi Perjuangan Umat Model Gus Dur dan Amien Rais, Yogyakarta: Pustaka Pelajar, Cet. I. 1997.

${ }^{24}$ Lihat Supartono Widyosiswoyo, Sejarah, Klaten: Intan, 1979, h. 187.
}

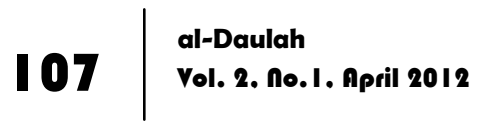


tersebut, paling tidak ada tiga kiai yang mempunyai andil besar dalam menyusun Pancasila. Oleh karena itu, tidak mengherankan jika terdapat delapan kosa-kata dari khazanah Islam yang masuk dalam Pancasila, yaitu: adil, beradab, kerakyatan, hikmat, permusyawaratan, perwakilah; dan terulangnya kosa-kata "adil dan rakyat" dalam sila kelima dari Pancasila.

Dengan melacak fakta sejarah di atas, terlihat betapa hubungan para kiai dengan Pancasila sangat erat sejak awal kemerdekaan, walaupun sering terjadi ketegangan antara umat Islam dan Pemerintah. Dalam hal ini, harus diakui bahwa di masa lalu pernah ada kesalahpahaman (mutual misunderstanding) antara Islam sebagai agama dan Pancasila sebagai ideologi negara. Kesalahpahaman itu barangkali lebih disebabkan adanya berbagai kepentingan politik, daripada dalam subtansinya. Sebenarnya, tidak perlu terjadi salah paham dalam hal yang menyangkut substansi karena substansi keduanya memang berbeda. Islam dalam agama dan Pancasila adalah ideologi. Permainan politiklah yang sebenarnya mengeksploitasi perbedaan tersebut supaya meruncing. ${ }^{25}$ Dalam konteks ini, Kuntowijoyo (1997:87) menambahkan bahwa kesalahannya tidak terletak pada ajaran yang murni dari keda belah pihak, tetapi dalam tanah praktik.

Gagasan Asas Tunggal menimbulkan pro dan kontra selama tiga tahun sampai diundangkan dalam UU nomor 5/1985 dan UU nomor 8/1985 tentang keharusan mendaftar ulang bagi ORMAS dan diberi batas akhir tanggal 17 Juli 1987. ORMAS yang tidak menerima Asas Tunggal tidak akan didaftar, dengan konsekuensi dibubarkan. Bagi kalangan Islam, gagasan tersebut menimbulkan masalah, bukan karena menolak Pancasila dan UUD 1945, melainkan ada kekhawatiran bahwa dengan menghapuskan asas "Islam", Pancasila akan menjadi "agama baru".

Dalam perkembangannya, justru para kiai yang tergabung dalam organisasi NU yang pertama kali menuntaskan penerimaan

\footnotetext{
${ }^{25}$ Lihat Kuntowijoyo, Identitas Politik Umat Islam, Bandung: Mizan, 1997, h. 79.
}

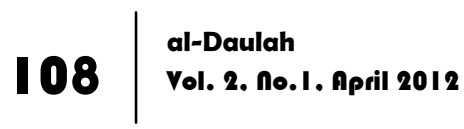


Pancasila sebagai Asas Tunggal. Bahkan KH. As'ad Syamsul Arifin menegaskan bahwa sebagian besar kiai dan umat Islam Indonesia berpendapat bahwa menerima Pancasila hukumnya wajib. ${ }^{26}$ Dalam konktes ini, Bruinessen (1992:136) menegaskan bahwa yang paling berperan dalam merumuskan penerimaan Asas Tunggal ini adalah KH. Ahmad Siddiq. Bahkan, dengan sangat meyakinkan ia mampu "membujuk" para kiai untuk menerima Pancasila dengan rumusan yang sesuai dengan paham Aswaja yang dianut oleh mereka.

Dengan pernyataan itu, Ahmad Siddiq bermaksud mengajak seluruh umat Islam di Indonesia untuk tidak ragu-ragu lagi mengisi kemerdekaan agar jangan bermimpi atau berangan-angan untuk membentuk negara lain selain negara Pancasila, dikarenakan negara Pancasila adalah "bentuk final" dari Negara Kesatuan Republik Indonesia. Lebih lanjut KH. Ahmad Siddiq mengingatkan bahwa umat Islam harus mengembangkan rasa persaudaraan (ukhuwwah). Hal ini didasarkan pada interpretasi atas kosa-kata umat. Baginya, sepanjang zaman kenabian, kosakata umat memuat sekaligus tiga pengertian. Yaitu persaudaraan seagama yang merujuk pada cita-cita terjalinnya hubungan yang harmonis dan saling menghormati di antara berbagai kelompok umat Islam (ukhuwah Islamiyyahi), persaudaraan kebangsaan (ukhuwwah Wathaniyyah), dan persaudaraan sesama manusia (ukhuwwah basyariyyah. ${ }^{27}$ Kedua konsep yang disebut terakhir ini lebih menjamin adanya keterbukaan dan toleransi kepada kalangan non-musim Indonesia serta adanya kepedulian terhadao isu-isu yang lebih global dari pada parokhial. Hal ini membuktikan bahwa sejak zaman pejajahan sampai era pascaOrde Baru, para kiai mampu mengikuti perkembangan zaman dengan tetap mengakar dalam tradisi dan tidak membang

\footnotetext{
${ }^{26}$ Lihat Maksoem Machfoedz, Kebangkitan Ulama dan Bangkitnya Ulama, Surabaya: Yayasan Kasatuan Umat, t.t, h. 40.

27 Lihat Marin van Bruinewwe, NU, Tradisi, Relasi-Relasi Kuasa, Pencarian Wacana Baru, Yogyakarta: LkiS, 1994, h. 147
} 
identitas Sunni-nya. Ini membuktikan bahwa Islam tradisional dapat memainkan peranan kreatif dalam dunia modern (bruinessen, 1994: 261).

\section{Kalangan Kiai Membaca Negara}

Keengganan NU membicarakan negara Islam sebenarnya bukanlah suatu yang luar biasa. NU yang didominasi oleh para kiai pesantren memang tidak mempunyai referensi yang kokoh tentang konsep negara Islam. Nalar fikih yang begitu domina di kalangan NU bersifat inklusif-internal yang mempunyai keterkaitan dengan persoalan sosial dan berorientasi sosial dengan menempatkan umat Islam sebagai subyek dan non Muslim sebagai objek. Misalnya, fikih Islam mengenal tema "kafir harby" dan "dzimmy". Kedua inisial tersebut bukan untuk ilustrasi superioritas muslim atas non Muslim. Sebaliknya, keduanya hanya sebatas identifikasi atas kelompok manusia dari sisi agama. Contoh teks fikih klasik yang terdapat dalam kitab al-Bughyatul Mustarsidin, dapat dijadikan contoh analisa:

"Setiap daerah yang dikuasai oleh kafir harby, sedangkan di tempat tersebut terdapat umat Islam yang sebelumnya pernah berkuasa, maka status daerah tersebut dalam perspektif Islam masih disebut dengan daerah Islam, meskipun secara formal diperintah oleh kafir harby. Karena itu segala ketentuan dan syariat Islam masih tetap berlaku di kalangan umatnya."

Redaksi di atas sekilas menggambarkan arogansi Islam sebagai agama yang tidak mengakui realitas sosial. Namun jika dianalisa, terdapat dua substansi yang ingin disampaikan: pertama, dalam fikih klasik berkembang pendapat bahwa Islam memberikan kebebasan kepada umatnya untuk menjalankan ajaran agama di manapun mereka berada. Redaksi, "segala ketentuan Islam tetap berlaku" sering dibahasakan secara sederhana oleh kiai pesantren dengan sebuah analogi, misalnya, jika ada sosok mayat ditemukan di jalan, maka negara tidak mempunyai kewajiban untuk mengurusnya, tetapi umat Islam 
(sebagai penduduk mayoritas) berkewajiban mengurusnya tanpa harus menyelidiki terlebih dahulu latas belakang agamanya. Artinya, persoalan kemasyarakatan yang melingkupi umat manusia di mana muslim berada di dalamnya tidak boleh terganggu hanya karena persoalan atau politik praktis.

Kedua, para kiai NU memahami bahwa fikih klasik telah memosisikan Islam sebagai agama saja (al-islam hua al-din). Nalar fikih tidak pernah membincang islam sebagai agama sekaligus kekuasaan politik (al-Islam hua al-din al-daulah). Beberapa bab dalam fikih-klasik memang ada yang menyiratkan Islam sebagai kekuatan politik, seperti dalam bab hudud (sanksi fisik pelaku seks bebas), jihad (perang membela kepentingan rakyat) atau riddah (sanksi fisik bagi orang murtad). Namun dalam persoalan tersebut fikih klasik hanya menyiapkan sebuah perangkat hukum Islam. Hukum Islam tersebut bisa efektif dilaksanakan oleh aparat hukum ketika disepakati menjadi hukum positif. Sebaliknya jika tidak, maka eksekusi ala fikih konteks ini tidak ada hukum Islam melainkan perangkat perundan-undangan negara.

Pemikiran NU tentang relasi syariat Islam dan negara mulai terkonsep dan menemukan bentuk ketika kemerdekaan RI memasuki masa-masa persiapan. KH Wahid Hasyim yang termasuk dalam panitia undang-undang dasar mengusulkan rumusan: "Agama negara adalah Islam dengan jaminan bagi pemeluk agama lain untuk dapat beribadah menurut agama masing-masing."

KH Wahid Hasyim juga mengusulkan bahwa presiden dan wakilnya harus beragama Islam.usulan beliau disebut-sebut sebagai aspirasi NU yang bersifat solutif di jalan tengah antara tokoh Muhammadiyah dan nasionalis. Bahkan pada 16 Juli 1954, Soekarno menyerukan kaum nasionalis agar menerima usulan NU tersebut. Mungkin benar analisa Andree Feilard bahwa gagasan KH. Wahid Hasyim di atas merupakan jalan tengah bagi dua kutub yang saling mengeras. Namun jika dianalisa dari sisi fikih klasik, gagasan tersebut justru berdiri sendiri dan tidak ada keterkaitan dengan jalan tengah atau mungkin secara kebetulan 
berposisi sebagai jalan tengah. Sebab dalam literatur-literatur fikih klasik sangat lumrah membincang kriteria, norma-norma, batasanbatasan nilai-nilai dan sejenisnya tapa harus di tuntaskan dengan wujud formulasi atas norma-norma tersebut.

Hal ini tampak dari reaksi para kiai NU terhadap Soekarno yang mengkritik substansi fikih. Kritik kiai NU terhadap Soekarno pada saat itu sebatas pelurusan atas kelaliman beliau dalam memahami substansi fikih klasik. Sedangkan gagasan Soekarno tentang pemisahan agama dan negara, lolos dari kritik pedas para kiai NU. Menurut para kiai, Soekarno gagal memahami fikih klasik yang ia tuduh sebagai penyebab keterbelakangan masyarakat muslim. Nalar politik para kiai NU yang berlatar belakang fikih klasik ini secara otomatis menggugurkan tesis-tesis ajaran Barat yang mengatakan bahwa banyak ulama yang mengharapkan Indonesia menjadi negara Islam. Cita-cita negara Islam tidak populer di kalangan Islam pesantren, tetapi laku keras di komunitas non pesantren. Gerakan Darul Islam menyebar di Jawa Barat, tetapi juga mempunyai presensi di Jawa tengah, Kalimantan Selatan, Sulawesi Selatan, Aceh dan tidak di Jawa Timur yang nota bene pusat gerakan NU dan nasionalis. Bahkan pada 16 Juli 1954 Soekarno menyerukan kaum nasionalis agar menerima usulan NU tersebut. Mungkin benar analisa Andree Feilard bahwa gagasan $\mathrm{KH}$ Wahid Hasyim di atas merupakan jalan tengah bagi dua kutub yang saling mengeras.

Namun jika dianalisa dari sisi fikih klasik, gagasan tersebut justru berdiri sediri dan tidak aga keterkaitan dengan jalan tengah atau mungkin secara kebetulan berposisi sebagai jalan tengah. Sebab dalam literatur-literatur fikih klasik sangat lumrah membincang kriteria, norma-norma, batasan-batasan nilai-nilai dan sejenisnya tanta harus dituntaskan dengan wujud formulasi atas norma-norma tersebut. Hal ini tampak dari reaksi para kiai NU terhadap Soekarno yang mengkritik substansi fikih. Kritik kiai NU terhadap Soekarno pada saat itu sebatas pelurusan atas kekliruan Soekarno dalam memahmi subtansi fikih klasik. 
Sedangkan gagasan Soekarno tentang pemisahan agama dan negara, lolos dari kritik pedas para kiai NU. Menurut kiai NU, Soekarno gagal memahami fikih klasik yang ia tuduh sebagai penyebab keterbelakangan masyarakat Muslim.

\section{NU dalam Wacana Kebangsaan}

Selain melengkapi wacana pemikiran paham keagamaan, berdirinya NU pada tanggal 31 Januari 1926, juga merupakan jawaban umat Islam untuk berkiprak dalam memperkuat barisan kebangkitan nasional. KH. Achmad Siddiq manilai kehadiran NU merupakan upaya untuk melembagakan wawasan tradisi keagamaan yang sudah dianut jauh sebelumnya, yaitu paham ahlussunnah wa al-Jama'ah (Aswaja). ${ }^{28}$ Sedangkan Ahmad Mansur Suryanegara menilai, berdirinya NU dipengaruhi kondisi politik dalam dan luar negeri, sekaligus merupakan kebangkitan kesadara politik yang ditampakkan dalam wujud gerakan jam'iyah (organisasi) dalam menjawab kepentingan nasional, dan dunia Islam umumnya. ${ }^{29}$

Perjuangan merebut dan mempertahankan kemerdekaan bangsa tidak lepas dari peran NU. Pembentukan tentara SabilillahHizbullah, keterlibatan KH Wahid Hasyim dalam BPUPKI, dan adanya Resolusi Jihad oleh KH Hasyim Asy'ari yang menetapkan fatwa fardhu 'ain (wajib) hukumnya untuk mempertahankan kemerdekaan, merupakan wujud peran aktif NU dalam kehidupan berbangsa dan bernegara. ${ }^{30}$

Pada masa Orde Baru, NU merupakan organisasi kemasyarakatan Islam yang memelopori penerimaan Pancasila sebagai satu-satunya asas organisasi. Hal ini merupakan wujud dari pemikiran politik NU dengan pendekatan keagamaan yang

\footnotetext{
${ }^{28}$ Achmad Siddiq, Khittah Nahdliyah, Surabaya: Balai Buku, 1980, h. II.

29 Ahmad Mansur Suryanegara, NU Lahir untuk Menjawab Tantangan Politik, Harian Sinar Harapan, 30 Januari 1985, serta pernah dimuat di Majalah Bulanan Nahdlatul Ulama Aula, No. 4 tahun VII, April 1985, h. 26-30.

${ }^{30}$ Baca Suplemen Harian Pagi, Republika, edisi jum'at I I Agustus 1995.
}

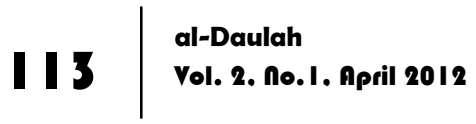


ditetapkan dalam bentuk Deklarasi tentang Hubungan Pancasila dengan Islam, yang isinya sebagai berikut:

1. Pancasila sebagai dasar dari falsafah Negara Republik Indonesia bukanlah agama, tidak dapat menggantikan agama dan tidak dapat dipergunakan untuk menggantikan kedudukan agama.

2. Sila Ketuhanan Yang Maha Esa sebagai Dasar Negara Republik Indonesia menurut pasal 29 ayat (1) Undang-Undang Dasar 1945, yang menjiwai sila-sila yang lain, mencerminkan tauhid menurut pengertian keimanan dalam Islam.

3. Bagi Nahdlatul Ulama, Islam adalah aqidah dan syariah, meliputi aspek hubungan antar manusia.

4. Penerimaan dan pengamalan Pancasila merupakan perwujudan dari umat Islam Indonesia untuk menjalankan syariat agamanya.

5. Sebagai konsekuensi dari sikap di atas, Nahdlatul Ulama berkewajiban mengamankan pengertian yang benar tentang Pancasila dan pengamalannya yang murni dan konsekuen oleh semua pihak. ${ }^{31}$

Dalam kaitannya dengan wawasan kebangsaan, pemikiran politik NU selalu memadukan antara nilai kebangsaan dengan nilai keagamaan (Islam). Perpaduan antara keduanya didasarkan pada landasan hukum Islam yang memberikan pedoman bahwa Islam tidak mengenal pemisahan agama dari politik. Menurut Gus Dur, hubungan antara agama dan negara harus terjalin secara proporsional. Hal ini dimaksudkan agar proses berfikir kaum muslimin tidak mengganggu perkembangan negara yang sedang merintis dan membangun tatanan negara yang mantap dan berfungsi untuk jangka panjang. ${ }^{32}$ Sikap politik tersebut

\footnotetext{
${ }^{31}$ Keputusan Muktamar NU ke-27, Nahdlatul Ulama Kembali ke Khittah 1926, Bandung: Risalah, tt, h. 50-5I.

32 Abdurrahman Wahid, Beberapa Aspek Teori dan Pemikiran Politik dan Negara Islam, dalam $\mathrm{KH}$ Imron Hamzah dan Choirul Anam (peny) Gus Dur Diadili Kiai-Kiai, Surabaya: Jawa Pos, 1989, h. 100.
} 
merupakan perwujudan dan perpaduan antara wawasan keagamaan dengan wawasan kebangsaan.

Menurut Gus Dur, secara garis besar paradigma agama dan negara ada tiga bentuk. Pertama, agama dan negara menyatu dan tidak dapat dipisahkan (integrated). Wilayah agama berarti juga wilayah politik. Kepala negara menjalankan kekuasaannya atau dasar kedaulatan Tuhan. Paradigma Syi'ah dengan konsep imamah (keimaman), bay'ah (janji setia), walaayah (kecintaan), dan ishmah (suci) bagi para mullah (pemimpin agama). Kedua, hubungan agama dan negara bersifat simbiotik atau timbal balik dan saling memerlukan. Ibnu Khaldun penulis buku Muqaddimah, al-Ghazali penulis buku Nashihat al-Muluk, dan Mawardi penulis buku alAhkamu al-Syulthaniyah cenderung mendekati konsep ini. Ketiga, hubungan antara agama dengan negara bersifat sekularistik. Agama terpisah sama sekali dengan politik, demikian juga sebaliknya. Dalam hubungan ini, Islam ditolak sebagai dasar negara atau menolak determinasi Islam sebagai bentuk tertentu sesuatu negara. Ibnu Taimiyah cenderung mendekatinya, lebihlebih Ali Abdul al-Raziq dalam risalahnya al-Islam wa Ushul Hukm. ${ }^{33}$

Berdasarkan sikap politik kemasyarakatan tersebut dan sesuai dengan budaya politik Indonesia, pemikiran politik NU selalu terbingkai pada sikap selektif, akomodatif, dan integratif dengan tetap memegang teguh nilai dan prinsip dasar yang telah ditetapkan. Sikap demikian diterapkan oleh NU dalam menjawab setiap permasalahan baru yang muncul dan mencarikan pemecahannya tanpa menimbulkan gejolak.

\footnotetext{
${ }^{33}$ Abdurrahman Wahid, Masih Relevankah Teori Kenegaraan Islam; Tinjauan Kontemporer atas Prinsip-Prinsip Rekontruksinya, dalam Universalime Islam dan Kosmopolitansi Peradaban Islam, Kumpulan karangan edisi terbatas, Jakarta: tp., 1991, h. 7-12.
} 


\section{Daftar Pustaka}

Adnan, Zifirdaus, Islam Religion Yes, Political Ideology No. Islam and the State in Indonesia, dalam artikel Arief Budiman, State and Civil Society (Clyton, Victoria: Centre of South East Asian Studies, 1992).

Affandi, Arief, Islam, Demokrasi Atas Bawah, Polemik Strategi Perjuangan Umat Model Gus Dur dan Amien Rais, 1997, Yogyakarta: Pustaka Pelajar, Cet. I.

Baqir, Haidar, "Republik Islam Iran; Revolusi menuju Teodemokratis", dalam Imam Azis, Agama, Demokrasi dan Keadilan, 1993, Jakarta: Gramedia.

Bruinewwe, Marin van, NU, Tradisi, Relasi-Relasi Kuasa, Pencarian Wacana Baru, 1994, Yogyakarta: LkiS.

Dirjk, C. Van, Darul Islam; Sebuah Pemberontakan, Jakarta: 1984, Grafiti Pres.

Harvey, S, Permesta; Pemberontakan Setengah Hati, 1984, Jakarta: Grafiti Pres.

Hasan, Muhammad Kamal, Modernisasi Indonesia; Respon Cendekiawan Muslim, 1987, Surabaya: Bina Ilmu.

Ida, Laode, Kembali ke Khittah 1926, Membangun Gerakan Politik Kultural NU, 1995, dalam Prisma

Jackson, Karl D, Kewibawaan Tradisional, Islam dan Pemberontakan; Kasus Darul Islam di Jawa Barat, 1990, Jakarta: Grafiti.

Jamil, Fathurrahman, Al-Mawardi, Mekanisme Pengangkatan dan Pemberhentian Kepala Negara, dalam Sudarnoto Abdul Hakim, Islam Berbagai Perspektif, 1995, Jakarta: LPMI.

Jauhari, Ahmad, Pemikiran Mawdudi tentang Negara Islam, dalam Sudarnoto Abdul Hakim, Islam berbagai Perspektif, 1995, Jakarta: LPMI.

Keputusan Muktamar NU ke-27, Nahdlatul Ulama Kembali ke Khittah 1926, Bandung: Risalah.

Kuntowijoyo, Identitas Politik Umat Islam, 1997, Bandung: Mizan. 
Machfoedz, Maksoem, Kebangkitan Ulama dan Bangkitnya Ulama, Surabaya: Yayasan Kasatuan Umat, t.t.

Pour, Julius, Benny Moerdani; Profil Prajurit Negarawan, 1993, Jakarta: Yayasan Kejuangan Panglima Sudirman.

Sadzali, Munawir, Islam dan Tata Negara; Ajaran Sejarah dan Pemikiran, 1995, Jakarta: UI Press.

Siddiq, Achmad, Khittah Nahdliyah, 1980, Surabaya: Balai Buku.

Smith, Donald Eugene, Agama dan Modernisasi Politik, suatu Kajian Analitis, 1985, Jakarta: Rajawali Press.

Suparlan, Parsudi, Kata Pengantar dalam Roland Robertson, Agama dalam Analisa dan Interpretasi Sosiologis, 1998, Jakarta: Rajawali Press.

Surbakti, Ramlan, Antara Fenomena Keagamaan dan Ekonomi-Politik, dalam Surabaya Post, 20 Oktober 1996.

Suryanegara, Ahmad Mansur, NU Lahir untuk Menjawab Tantangan Politik, Harian Sinar Harapan, 30 Januari 1985,

Syamsudin, Din, Usaha Pencarian Konsep Negara dalam Sejarah Pemikiran Politik Islam, dalam Ulumul Qur'an, 1993, no. 2, vol. IV.

Wahid, Abdurrahman, Beberapa Aspek Teori dan Pemikiran Politik dan Negara Islam, dalam KH Imron Hamzah dan Choirul Anam (peny) Gus Dur Diadili Kiai-Kiai, 1989, Surabaya: Jawa Pos.

---------, Masih Relevankah Teori Kenegaraan Islam; Tinjauan Kontemporer atas Prinsip-Prinsip Rekontruksinya, dalam Universalime Islam dan Kosmopolitansi Peradaban Islam, Kumpulan karangan edisi terbatas, 1991, Jakarta: tp.

---------, Poitik Sebagai Moral, Bukan Institusi, 1995, dalam Prisma, No. 5.

Watt, W. Montgomery, Politik Islam dalam Lintasan Sejarah, 1988, Jakarta: P3M.

Widyosiswoyo, Supartono, Sejarah, 1979, Klaten: Intan.

Departemen Penerangan, Pidato Kenegaraan Republik Indonesia Soeharto di Depan Dewan Perwakilan Rakyat, 16 Agustus 1982. 
Majalah Bulanan Nahdlatul Ulama Aula, No. 4 tahun VII, April 1985.

Harian Panji Masyarakat, 21 September 1984.

Harian Sinar Harapan, 1 Juni 1985,

Tempo, 30 September 1989,

Tempo, 18 Februari 1989.

Harian Pagi, Republika, edisi jum'at 11 Agustus 1995 